\title{
Diversity Among Potato virus $Y$ Isolates Obtained from Potatoes Grown in the United States
}

\author{
L. M. Piche, R. P. Singh, X. Nie, and N. C. Gudmestad
}

First and fourth authors: Department of Plant Pathology, North Dakota State University, Fargo 58105; and second and third authors: Potato Research Centre, Agriculture and Agri-Food Canada, P.O. Box 20280, Fredericton, NB, Canada E3B $4 Z 7$. Accepted for publication 2 September 2004.

\begin{abstract}
Piche, L. M., Singh, R. P., Nie, X., and Gudmestad, N. C. 2004. Diversity among Potato virus $Y$ isolates obtained from potatoes grown in the United States. Phytopathology 94:1368-1375.

Potato field isolates (Solanum tuberosum) of Potato virus $Y$ (PVY) collected from the midwestern and western United States were characterized using serological, molecular, and biological assays. PVY field isolates were grouped into the previously defined categories: PVYO, European PVYNTN, North American PVYNTN, and PVY ${ }^{\mathrm{N}: \mathrm{O}}$ recombinant and four previously undefined groups. Studies reported here agree with published reports from Europe and elsewhere in North America as PVY isolates capable of causing veinal necrosis in tobacco indicator plants

appear in high frequency. In contrast to European experiences, PVY tuber necrosis isolates have a $\mathrm{PVY}^{\mathrm{O}}$ coat protein rather than that of $\mathrm{PVY}^{\mathrm{N}}$. Several PVYN:O recombinant isolates induced potato tuber necrotic ringspot disease (PTNRD) in the highly susceptible potato cv. Yukon Gold. The PTNRD symptoms produced by these PVY ${ }^{\mathrm{N}: \mathrm{O}}$ recombinants were atypical compared with lesions found on the same cultivar infected with either the European or North American PVY ${ }^{\mathrm{NTN}}$ isolates. These PVYN:O isolates produced a roughly circular, sunken necrotic lesion on the surface of the tuber instead of the typical external sunken ring pattern displayed by PVYNTN isolates. This study establishes the complex nature of PVY populations within the U.S. potato industry and clearly demonstrates the diverse nature of PVY in the United States.
\end{abstract}

Potato virus $Y$ (PVY) belongs to the largest plant virus family, Potyviridae. The most common PVY strains affecting potatoes are differentiated by reaction on potato (Solanum tuberosum L.) and tobacco (Nicotiana tabacum L.). Several strains of PVY are known. PVYO (the "ordinary" strain) is ubiquitous among potato production areas, causing mild to severe mosaic symptoms, depending on the cultivar. This PVY strain was first classified in 1931 (31) and has recently become epidemic throughout the United States (7). The widespread nature of PVY may be largely due to potato cultivars being grown that do not express symptoms of the disease, compromising seed certification and regulatory inspections (7). $\mathrm{PVY}^{\mathrm{C}}$ induces stipple streak symptoms in potato cultivars bearing the $N c$ gene. $\mathrm{PVY}^{\mathrm{Z}}$ overcomes resistance genes effective against both $\mathrm{PVY}^{\mathrm{O}}$ and $\mathrm{PVY}^{\mathrm{C}}(10,12)$.

In the 1950s, a new tobacco veinal necrosis strain of PVY $\left(\mathrm{PVY}^{\mathrm{N}}\right)$ was found in Europe and South America and has since spread worldwide, eventually being detected in North America in $1990(15,28) . \mathrm{PVY}^{\mathrm{N}}$ is frequently symptomless or produces mild to severe mosaic symptoms in potatoes along with severe veinal necrosis and leaf death in tobacco. Nonetheless, several reports have associated $\mathrm{PVY}^{\mathrm{N}}$ with yield and quality losses in resistant or symptomless potatoes $(7,9)$. A variant of $\mathrm{PVY}^{\mathrm{N}}$, termed $\mathrm{PVY} \mathrm{NTN}^{\mathrm{N}}$, includes isolates that cause potato tuber necrotic ringspot disease (PTNRD) and belong to the necrotic group (N) of PVY based on serology and the ability to induce veinal necrosis symptoms in tobacco $(13,35)$. PVY ${ }^{\mathrm{NTN}}$ was first observed in Hungary in the late 1970s (1), and more recently in many potato production areas worldwide, including North America in 1993 (16). PVY ${ }^{\mathrm{NTN}}$ isolates can cause severe chlorotic mosaic symptoms on potato leaves in addition to PTNRD. PTNRD is characterized by the

Corresponding author: N. C. Gudmestad

E-mail address: neil.gudmestad@ndsu.nodak.edu

Publication no. P-2004-1018-02R

(C) 2004 The American Phytopathological Society appearance of external rings on the surface of tubers. Initially these rings protrude, later becoming sunken and necrotic with symptoms growing more pronounced during storage. The disease reduces tuber quality, with the necrotic symptoms rendering affected tubers unsuitable for fresh market, processing, or seed. A major difficulty in screening for PVY isolates that cause tuber necrosis is that they cannot be distinguished from $\mathrm{PVY}^{\mathrm{N}}$ using current serological methods $(33,34)$.

More recently, isolates resembling $\mathrm{PVY}^{\mathrm{N}}$ in tobacco, which are serologically related to $\mathrm{PVY}^{\mathrm{O}}$, have been reported. For instance, PVYN ${ }^{\mathrm{N}}$-Wilga was first described in 1991 in Europe, along with isolates I-L56 and I-136, both isolated in 1992 in North America $(3,18,19)$. Analysis of nucleotide sequences of PVY ${ }^{\mathrm{N}}-$ Wilga and European (Eu) PVY ${ }^{\mathrm{NTN}}$ indicates that both are recombinant isolates, with a genome comprised of segments from $\mathrm{PVY}{ }^{\mathrm{O}}$ and $\mathrm{Eu}$ PVY $^{\text {NTN }}$ (8). By targeting three major recombinant junctions in the genome of Eu PVY ${ }^{\mathrm{NTN}}$, a multiplex reverse transcription-polymerase chain reaction (RT-PCR) assay was developed (22). Separate primer pairs were designed to bind to the recombinant junctions located at the HC/Pro-P3 gene region, the 6K2-NIa gene region, and the C-terminal region of the coat protein $(\mathrm{CP})$ gene $(22)$. Recombinant isolates sharing a $\mathrm{PVY}^{\mathrm{O}}$ coat protein have become common in certain regions of North America and are presently referred to as $\mathrm{PVY}^{\mathrm{N}: \mathrm{O}}(5,25,30)$. In the absence of full-length sequences, only one recombination junction site has been found to exist in $\mathrm{PVY}^{\mathrm{N}: \mathrm{O}}$ isolates at the HC/Pro-P3 region using the multiplex RT-PCR assay (22). The PVYN:O recombinant isolates studied so far, along with PVY ${ }^{\mathrm{N}}$-Wilga, have not been shown to induce tuber necrosis symptoms in potato $(22,30)$.

The diagnosis of tuber necrosis-inducing isolates of PVY has become difficult due to the increasing numbers of recognized isolates and the incidence of mixed infections. Numerous efforts have been initiated to characterize PVY isolates using an RT-PCR assay targeting specific areas of the genome $(2,20,21,36)$. The P1 gene region has been proposed to be the least conserved region 
among potyviruses (6) and also within strains of PVY (14). An RT-PCR assay, based on sequence variation within the P1 gene, has allowed PVY isolates to be initially categorized as either $\mathrm{PVY}^{\mathrm{O}}$ or PVY $\mathrm{PV}^{\mathrm{N} / \mathrm{NTN}}$ (21), allowing the potential PTNRD-inducing isolates to be separated from innocuous $\mathrm{PVY}^{\mathrm{O}}$ isolates. This duplex RT-PCR assay also will detect mixed infections of several PVY pathotypes but not differentiate a mixed infection of several isolates of the same pathotype. A subsequent RT-PCR assay targeting three major recombination junctions allows further separation of $\mathrm{PVY}^{\mathrm{N} / \mathrm{NTN}}$ isolates into recombinant, such as Eu PVY ${ }^{\mathrm{NTN}}$; nonrecombinant, represented by North American PVY ${ }^{\text {NTN }}$ (NA $\mathrm{PVY}^{\mathrm{NTN}}$ ); and $\mathrm{PVY}^{\mathrm{N}: \mathrm{O}}$ recombinant isolates (22).

The objective of this study was to characterize and differentiate field isolates obtained from various potato production regions in the United States. Further, we wanted to assess the PVY population and to determine the frequency with which isolates group into the current classification of PVY strains based on a combination of enzyme-linked immunosorbent assay (ELISA), RT-PCR, and bioassays, and to determine the extent and relative importance of PTNRD-producing isolates.

\section{MATERIALS AND METHODS}

PVY isolates. A total of 193 tuber and leaf samples were collected from fields originating in Idaho (ID), Minnesota (MN), North Dakota (ND), Nebraska (NE), Nevada (NV), Oregon (OR), and Texas (TX), during 2001 to 2003. Samples were generally collected by one of the authors or at their request (N. C. Gudmestad). Leaf samples submitted to our laboratory of unknown origin were labeled "Unk". All original samples were tested initially using serological and RT-PCR assays and then stored as freeze-dried leaf tissue at $-80^{\circ} \mathrm{C}$. Of the 193 original samples, 58 were further selected based on serological properties, molecular analysis, and representative geographic region to be multiplied in tobacco cv. Samsun and subsequently characterized using serology, RT-PCR, and bioassays (Table 1). A sample of the infected tobacco tissue also was stored as freeze-dried leaf tissue at $-80^{\circ} \mathrm{C}$.

Serological identification of viral isolates. Compound direct ELISA was conducted on the 193 PVY isolates using either the original potato leaf tissue or the fresh infected tobacco leaf tissue to corroborate PVY infection and to serologically identify the isolates using three PVY monoclonal antibodies distributed by Agdia (Elkhart, IN). Monoclonal antibody 4C3 is a general antibody that detects all PVY isolates (PN 20001), MAB2 is a monoclonal antibody specific for $\mathrm{PVY}^{\mathrm{O}+\mathrm{C}}$ (PN 20600), and monoclonal antibody 1F5 is specific for $\mathrm{PVY}^{\mathrm{N}}$ (PN 26001). A Potato virus $X$ (PVX) ELISA (PN 10000) also was conducted to rule out synergistic interactions, which could result in necrotic symptoms in tobacco bioassays (29). All reagents were obtained from Agdia, and the assays were carried out in triplicate according to manufacturer's instructions. Samples were considered positive if they produced an absorbance value twice the standard deviation of the healthy control.

Total RNA extraction. Total RNA was extracted either from original potato leaf or tuber tissue or from infected tobacco leaf tissue with the RNeasy Plant Mini Kit (Qiagen, Valencia, CA). Leaf and tuber tissue were ground in liquid nitrogen with an oven-baked $\left(240^{\circ} \mathrm{C}\right.$ for $\left.4 \mathrm{~h}\right)$ sterilized mortar and pestle. A sample of the powdered tissue (approximately $100 \mathrm{mg}$ ) was extracted for total RNA according to the manufacturer's instructions. Total RNA was eluted in $50 \mu \mathrm{l}$ of RNase-free water and centrifuged for $1 \mathrm{~min}$ at $8,000 \times g$. The resulting RNA was stored at $-80^{\circ} \mathrm{C}$.

RT-PCR. Four microliters of concentrated total RNA extract was diluted with $6 \mu \mathrm{l}$ of RNase-free water to reduce nonspecific amplification (30), incubated at $65^{\circ} \mathrm{C}$ for $8 \mathrm{~min}$, and chilled on ice for $3 \mathrm{~min}$. To the denatured RNA extract, $15 \mu \mathrm{l}$ of RT reaction mixture (1× M-MLV RT Buffer [Promega, Madison, WI], $1.5 \mathrm{mM}$ each dNTP [Roche, Indianapolis, IN], 20 units of RNasin [Promega], $1 \mu \mathrm{M}$ Random Hexamers [Applied Biosystems, Foster City, CA], and 200 units of M-MLV reverse transcriptase [Promega]) was added to provide a final volume of $25 \mu$ l. Samples were incubated at $42^{\circ} \mathrm{C}$ for $1 \mathrm{~h}$ followed by $95^{\circ} \mathrm{C}$ for $3 \mathrm{~min}$ to terminate the RT reaction. The resulting cDNA was stored at $-20^{\circ} \mathrm{C}$.

Separate duplex, triplex, and recombinant point RT-PCRs were carried out using primer sequences and reaction conditions previously reported $(21,22)$. Duplex PCR for distinguishing $\mathrm{PVY}^{\mathrm{O}}$ from $\mathrm{PVY}^{\mathrm{N} / \mathrm{NTN}}$ isolates was performed using $5 \mu \mathrm{l}$ of $\mathrm{cDNA}$ mixture in a final volume of $25 \mu$ containing $1 \times$ PCR Buffer (Qiagen), $3 \mathrm{mM} \mathrm{MgCl}_{2}$ (Qiagen), $4 \mathrm{mM}$ each dNTP (Roche), $0.5 \mu \mathrm{M}$ S6 and $\mathrm{S} 7$ forward primers, $1 \mu \mathrm{M}$ reverse primer $\mathrm{A}$, and 1 unit of Taq DNA polymerase (Qiagen). A triplex RT-PCR using forward primers S3, S5, and S6 and reverse primer A was carried out to confirm North American (NA) PVY ${ }^{\mathrm{NTN}}$ identity, using the same reagent concentrations listed above (21). Each isolate categorized as PVY $\mathrm{P}^{\mathrm{N} / \mathrm{NTN}}$ was further subjected to a multiplex PCR to determine if any of the three known recombination junctions were present within the genome. Again, $5 \mu \mathrm{l}$ of cDNA mixture was added to the recombinant point PCR mixture, which contained $1 \times$ PCR Buffer (Qiagen); $3 \mathrm{mM} \mathrm{MgCl}_{2}$ (Qiagen); $4 \mathrm{mM}$ each dNTP (Roche); $2 \mu \mathrm{M}$ each of $\mathrm{Sn}, \mathrm{S}_{5585}$, and $\mathrm{S}_{9133}$ forward primers; $2 \mu \mathrm{M}$

TABLE 1. Potato host variety, origin, field type, and collection year of Potato virus $Y$ (PVY) field isolates multiplied in tobacco and characterized by serological, biological, and molecular assays

\begin{tabular}{|c|c|c|c|c|}
\hline Isolates & Variety & Origin $^{\mathrm{a}}$ & Field type ${ }^{b}$ & Year collected \\
\hline ID-1 & Russet Burbank & Idaho (1) & $\mathrm{S}$ & 2003 \\
\hline $\mathrm{MN}-(1,2)$ & Alturas & Minnesota (2) & $\mathrm{C}$ & 2001,2003 \\
\hline ND- $(1-24,26-28)$ & Clonal Selections & North Dakota (27) & B & 2003 \\
\hline NE-15 & Atlantic & Nebraska (1) & $\mathrm{S}$ & 2003 \\
\hline NE-(1-3, 7, 10-13) & FL 1533 & Nebraska (8) & $\mathrm{S}$ & 2003 \\
\hline NE- $(5,6)$ & Pike & Nebraska (2) & $\mathrm{S}$ & 2003 \\
\hline NE- $(4,8,9)$ & Russet Burbank & Nebraska (3) & $\mathrm{S}$ & 2003 \\
\hline OR-1 & Alturas & Oregon (1) & $\mathrm{C}$ & 2001 \\
\hline TX-1 & Atlantic & Texas (1) & $\mathrm{C}$ & 2003 \\
\hline Unk-1 & Russet Burbank & Unknown (1) & $\mathrm{C}$ & 2002 \\
\hline Unk-(2-9) & Unknown & Unknown (8) & $\mathrm{C}$ & 2002 \\
\hline $\mathrm{PVY}^{\mathrm{O}}-139^{\mathrm{c}}$ & Tobacco & Canada (1) & $\ldots$ & 2003 \\
\hline Tu $660^{c}$ & Tobacco & Canada (1) & $\ldots$ & 2003 \\
\hline
\end{tabular}

${ }^{\mathrm{a}}$ Number of isolates recovered and tested listed in parentheses.

${ }^{\mathrm{b}}$ Type of field samples originated from $\mathrm{B}=$ breeding program selections, $\mathrm{C}=$ commercial field, or $\mathrm{S}=$ seed field.

${ }^{c}$ Control isolates PVYO-139 $\left(\mathrm{PVY}^{\mathrm{O}}\right)$ and Tu 660 (North American PVY ${ }^{\mathrm{NTN}}$ ) sent to us in 2003, but collected and characterized previously. 
each of Ao, $\mathrm{A}_{6032}$, and $\mathrm{A}_{9422}$ reverse primers (22); and 1 unit of Taq DNA polymerase (Qiagen). All PCRs were amplified as per Nie and Singh (20), using the same cycling conditions in the DNA Engine PTC200 (MJ Research, Waltham, MA). The amplified product $(10 \mu \mathrm{l})$ was separated on a $15 \%$ polyacrylamide gel electrophoresis (PAGE) gel, ran at 200 constant volts for $1 \mathrm{~h}$, and stained with ethidium bromide $(0.5 \mu \mathrm{g} / \mathrm{ml})$ or developed by silver staining.

Tobacco and potato bioassay. Fifty-eight PVY field isolates, selected according to their serological and molecular analysis with representative geographical location, were mechanically inoculated onto tobacco cv. Samsun and potato cv. Yukon Gold to determine pathotype. All plants were grown in a greenhouse at 15 to $18^{\circ} \mathrm{C}$ with $12 \mathrm{~h}$ light $\left(90 \mu \mathrm{m}^{-2} \mathrm{~s}^{-1}\right)$.

Tobacco plants at the three-leaf stage were lightly sprinkled with Carborundum powder prior to being mechanically inoculated with PVY potato leaf extracts, which were ground with a mortar and pestle in extraction buffer ( $0.01 \mathrm{M}$ sodium phosphate, $\mathrm{pH} 7.5$, containing $0.4 \%$ sodium sulfite) at a $1: 10(\mathrm{wt} / \mathrm{vol})$ ratio. Seven to ten days postinoculation, foliar symptoms were recorded daily for the next 15 to 20 days. Symptom development was compared with that of uninoculated control plants and plants inoculated with the control isolates $\mathrm{PVY}^{\mathrm{O}}-139$ and Tu 660 (NA PVY $\left.{ }^{\mathrm{NTN}}\right)(16,18$, 20-23,26,27,30,36).

Potato plants 15 to $20 \mathrm{~cm}$ tall with 8 to 10 fully developed leaves were mechanically inoculated with PVY-infected tobacco leaf extracts as described previously. Plants were monitored for foliar symptom development characteristic of PVY (mosaic, veinal necrosis, and leaf necrosis), and approximately 70 to 90 days postinoculation, potato tubers were harvested and rated for PTNRD symptoms immediately and after 2 to 6 weeks of storage in the dark at room temperature. All tobacco and potato plants mechanically inoculated were tested approximately 3 to 4 weeks after inoculation by both the duplex and recombinant point RTPCR to confirm infection status.

\section{RESULTS}

Serological identification of viral isolates. Of the 193 isolates, 135 were tested by ELISA using only the original potato leaf tissue. The remaining 58 isolates were tested using both the original potato leaf sample and the infected tobacco leaf tissue, with identical results. All of these samples tested for PVX by ELISA were negative for PVX infection. After confirming that the

TABLE 2. Mean serological absorbance values $\left(A_{405 \mathrm{~nm}}\right)$ and standard deviations (SD) of representative Potato virus $Y$ (PVY) isolates

\begin{tabular}{|c|c|c|c|c|c|c|c|c|}
\hline \multirow[b]{2}{*}{ Isolate } & \multicolumn{2}{|c|}{$4 C 3^{a}$} & \multicolumn{2}{|c|}{$\mathrm{MAB}^{\mathrm{a}}$} & \multicolumn{2}{|c|}{$1 F 5^{a}$} & \multicolumn{2}{|c|}{ Potato virus $X$} \\
\hline & $A_{405 \mathrm{~nm}}{ }^{\mathrm{b}}$ & $\mathrm{SD}^{\mathrm{b}}$ & $A_{405 \mathrm{~nm}}$ & SD & $A_{405 \mathrm{~nm}}$ & SD & $A_{405 \mathrm{~nm}}$ & SD \\
\hline $\mathrm{PVY}^{\mathrm{O}}-139^{\mathrm{c}}$ & 3.000 & 0.000 & 3.000 & 0.000 & 0.019 & 0.006 & 0.001 & 0.002 \\
\hline ND-5 & 3.000 & 0.000 & 3.000 & 0.000 & 0.016 & 0.004 & 0.001 & 0.002 \\
\hline NE-13 & 1.103 & 0.011 & 0.895 & 0.003 & 0.043 & 0.007 & 0.002 & 0.003 \\
\hline MN-1 & 3.000 & 0.000 & 3.000 & 0.000 & 0.029 & 0.003 & 0.003 & 0.003 \\
\hline ND-25 & 1.858 & 0.009 & 2.004 & 0.005 & 0.006 & 0.001 & 0.007 & 0.006 \\
\hline NV-1 & 3.000 & 0.000 & 2.624 & 0.016 & 0.019 & 0.002 & 0.001 & 0.004 \\
\hline OR-1 & 1.932 & 0.020 & 0.973 & 0.007 & 0.031 & 0.002 & 0.003 & 0.002 \\
\hline ID-1 & 0.918 & 0.017 & 1.099 & 0.001 & 0.018 & 0.002 & 0.047 & 0.002 \\
\hline ND-6 & 2.577 & 0.090 & 2.612 & 0.001 & 0.012 & 0.001 & 0.009 & 0.009 \\
\hline ND-27 & 2.684 & 0.002 & 1.612 & 0.027 & 0.031 & 0.005 & 0.006 & 0.002 \\
\hline NE-3 & 0.503 & 0.006 & 0.548 & 0.010 & 0.011 & 0.001 & 0.003 & 0.003 \\
\hline NE-7 & 1.152 & 0.006 & 1.334 & 0.013 & 0.044 & 0.004 & 0.003 & 0.002 \\
\hline NE-8 & 3.000 & 0.000 & 3.000 & 0.000 & 0.029 & 0.001 & 0.000 & 0.002 \\
\hline TX-1 & 3.000 & 0.000 & 2.133 & 0.019 & 0.024 & 0.007 & 0.007 & 0.004 \\
\hline Unk-3 & 3.000 & 0.000 & 3.000 & 0.000 & 0.022 & 0.006 & 0.035 & 0.003 \\
\hline $\mathrm{Tu} 660^{\mathrm{c}}$ & 1.461 & 0.006 & 0.077 & 0.010 & 1.592 & 0.008 & 0.001 & 0.004 \\
\hline NE-11 & 0.683 & 0.010 & 0.035 & 0.011 & 1.184 & 0.016 & 0.021 & 0.007 \\
\hline MN-2 & 3.000 & 0.000 & 0.033 & 0.007 & 1.931 & 0.035 & 0.001 & 0.005 \\
\hline Unk-1 & 3.000 & 0.000 & 0.034 & 0.017 & 1.537 & 0.029 & 0.001 & 0.006 \\
\hline Unk-2 & 1.933 & 0.019 & 0.019 & 0.022 & 1.430 & 0.033 & 0.001 & 0.003 \\
\hline Unk-4 & 1.058 & 0.016 & 1.059 & 0.005 & 1.295 & 0.037 & 0.000 & 0.002 \\
\hline Unk-5 & 0.981 & 0.001 & 0.896 & 0.006 & 0.612 & 0.022 & 0.001 & 0.003 \\
\hline Unk-6 & 1.120 & 0.024 & 1.152 & 0.009 & 0.896 & 0.013 & 0.003 & 0.009 \\
\hline Unk-7 & 0.993 & 0.027 & 0.810 & 0.007 & 0.761 & 0.019 & 0.001 & 0.003 \\
\hline Unk-8 & 1.070 & 0.007 & 0.375 & 0.015 & 1.599 & 0.008 & 0.004 & 0.006 \\
\hline Unk-9 & 0.905 & 0.006 & 0.460 & 0.010 & 1.224 & 0.014 & 0.002 & 0.002 \\
\hline Healthy control & 0.032 & 0.002 & 0.056 & 0.007 & 0.017 & 0.003 & 0.004 & 0.003 \\
\hline Positive control & 1.619 & 0.005 & 1.704 & 0.003 & 1.538 & 0.007 & 1.033 & 0.005 \\
\hline
\end{tabular}

${ }^{a}$ Monoclonal antibody 4C3 detects all PVY isolates; monoclonal antibodies MAB2 and 1F5 detect PVY ${ }^{\mathrm{O}+\mathrm{C}}$ and $\mathrm{PVY}$, respectively.

${ }^{b}$ SD using three replicates. Shaded areas represent a positive absorbance value.

${ }^{c}$ Control isolates PVYO-139 $\left(\mathrm{PVY}^{\mathrm{O}}\right)$ and Tu 660 (North American PVYNTN).

TABLE 3. Summary of responses of 193 Potato virus $Y$ (PVY) field isolates to monoclonal antibodies and reverse transcription-polymerase chain reaction (RT-PCR)

\begin{tabular}{|c|c|c|c|c|c|c|c|c|c|c|c|c|}
\hline & \multicolumn{5}{|c|}{ Enzyme-linked immunosorbent assay } & \multicolumn{4}{|c|}{ RT-PCR for P1 gene ${ }^{a}$} & \multicolumn{3}{|c|}{ Recombination points $^{b}$} \\
\hline & $4 C 3^{c}$ & $\mathrm{MAB} 2^{\mathrm{c}}$ & $1 \mathrm{~F} 5^{\mathrm{c}}$ & MAB2/1F5 & PVX & $281 \mathrm{bp}$ & $443 \mathrm{bp}$ & $554 \mathrm{bp}$ & 745 bp & 0 & 1 & 3 \\
\hline Number of isolates detected ${ }^{\mathrm{d}}$ & 193 & 166 & 18 & 9 & 0 & 10 & 183 & 0 & 181 & 11 & 158 & 24 \\
\hline Percent total & $100 \%$ & $86 \%$ & $9 \%$ & $5 \%$ & $0 \%$ & $5 \%$ & $95 \%$ & $0 \%$ & $94 \%$ & $6 \%$ & $82 \%$ & $12 \%$ \\
\hline
\end{tabular}


samples were infected with PVY using universal monoclonal antibody $4 \mathrm{C} 3$, the corresponding leaf samples were further tested by specific PVY monoclonal antibodies, MAB2 and 1F5, to differentiate $\mathrm{PVY}^{\mathrm{O}+\mathrm{C}}$ and $\mathrm{PVY} \mathrm{N}^{\mathrm{N}}$ infection, respectively. Based on antigenic specificity, the field isolates produced three differential responses to these PVY antibodies as depicted for representative PVY isolates (Table 2). Eighty-six percent (166 of the 193 isolates) were detected by monoclonal antibody MAB2 (Table 3), indicating presence of the $\mathrm{PVY}^{\mathrm{O}}$ coat protein. Along with the control isolate $\mathrm{Tu} 660$, only $9 \%$ (18 isolates) were detected by monoclonal antibody 1F5 recognizing the $\mathrm{PVY}^{\mathrm{N}}$ coat protein (Table 3). Nine isolates (5\%) reacted to both monoclonal antibodies MAB2 and 1F5 (Table 3), which could indicate either a mixed infection of both $\mathrm{PVY}^{\mathrm{O}}$ and $\mathrm{PVY}^{\mathrm{N}}$ or a recombination event combining coat protein segments of both $\mathrm{PVY}^{\mathrm{O}}$ and $\mathrm{PVY} \mathrm{Y}^{\mathrm{N}}$. These latter nine isolates were screened by a uniplex RT-PCR using $\mathrm{PVY}^{\mathrm{O}}$-specific primers ( $\mathrm{S} 7$ and $\mathrm{A}$ ) to rule out the possibility of a double infection involving a low concentration of $\mathrm{PVY}^{\mathrm{O}}$. All nine samples were negative for the PVYO $\mathrm{P} 1$ gene by uniplex RTPCR (data not shown), concluding that the reaction by both MAB2 and 1F5 was not due to a multiple infection of several PVY pathotypes.

Viral isolate detection by duplex, recombinant point, and triplex RT-PCR. Sense primers S6 and S7, in conjunction with the single reverse primer A, produced amplified products of 281 and 443 bp corresponding to the $\mathrm{P} 1$ gene of PVY ${ }^{\mathrm{O}}$ and PVY $\mathrm{Y}^{\mathrm{N} / \mathrm{NTN}}$, respectively (Fig. 1). The P1 gene duplex RT-PCR revealed that all 193 PVY field isolates fit into either the $\mathrm{PVY}^{\mathrm{O}}$ or the $\mathrm{PVY}^{\mathrm{N} / \mathrm{NTN}}$ category. Most $(95 \%)$ of the field isolates produced the 443-bp product (Table 3) and were initially considered to be members of the PVY ${ }^{\mathrm{N} / \mathrm{NTN}}$ group, along with control isolate Tu 660 (data not shown). The remaining 10 field isolates (5\%) and the control isolate $\mathrm{PVY}^{\mathrm{O}}-139$ each produced a 281 -bp product indicative of the $\mathrm{PVY}^{\mathrm{O}}$ group (Table 3 ).

A more detailed characterization of the PVY ${ }^{\mathrm{N} / \mathrm{NTN}}$ group (183 isolates) was accomplished through detection of three potential recombination junction sites, which have been found within recombinant molecules of various PVY isolates. Primer pairs $\mathrm{Sn} / \mathrm{Ao}, \mathrm{S}_{5585} / \mathrm{A}_{6032}$, and $\mathrm{S}_{9133} / \mathrm{A}_{9422}$ produced amplified products of 290,448 , and 641 bp corresponding to recombinant junction sites at the $\mathrm{C}$-terminal region of the $\mathrm{CP}$ gene, the $6 \mathrm{~K} 2$-NIa gene region, and the HC/Pro-P3 gene region, respectively (Fig. 2). This allowed specific differentiation of the PVY ${ }^{\mathrm{N} / \mathrm{NTN}}$ field isolates into several PVY pathotypes including recombinant isolates, PVYNTN and $\mathrm{PVY}^{\mathrm{N}: \mathrm{O}}$, and nonrecombinant isolates. The 10 field isolates

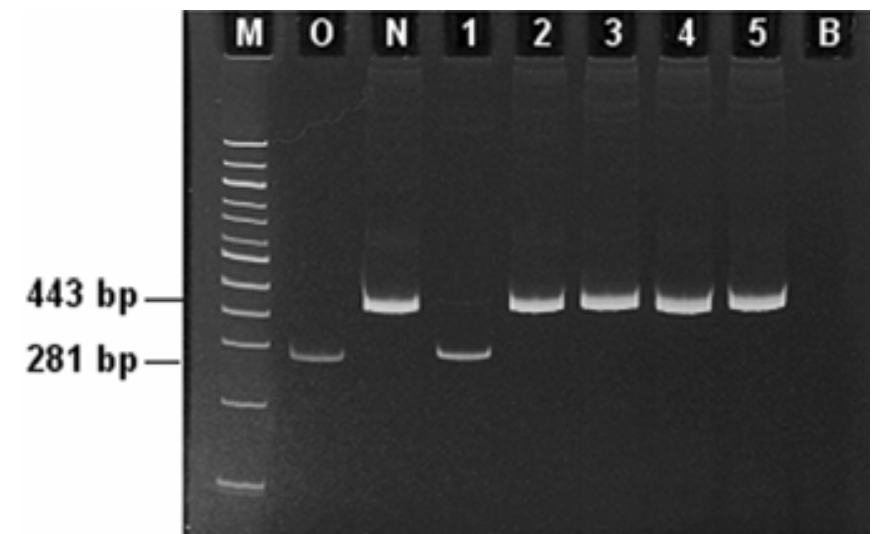

Fig. 1. Duplex reverse transcription-polymerase chain reaction detecting segments of the P1 gene using primers S6, S7, and A in representative Potato virus $Y$ (PVY) isolates using RNA isolated from tobacco plants. Lane $\mathrm{M}$, 100-bp DNA ladder; lane O, PVY ${ }^{\mathrm{O}}$ positive control; lane $\mathrm{N}, \mathrm{PVY}^{\mathrm{N} / \mathrm{NTN}}$ positive control; lane $1, \mathrm{PVY}^{\mathrm{O}}$ sample; lane $2, \mathrm{PVY}^{\mathrm{N}: \mathrm{O}}$ recombinant sample; lane 3, North American PVYNTN sample; lane 4, European (Eu) PVYNTN sample; lane 5, Eu PVY ${ }^{\mathrm{NTN}}$ sample; and lane B, negative control. from the initial $\mathrm{PVY}^{\mathrm{O}}$ group, along with the control isolate $\mathrm{PVY}^{\mathrm{O}}$ 139 , did not contain any of the three recombination sites, as expected (Table 4). The remaining $\mathrm{PVY}^{\mathrm{N} / \mathrm{NTN}}$ field isolates were further divided based on the number of recombination junctions present within the genome based on the three known junction sites, according to the recombinant point RT-PCR. A total of 24 field isolates (12\%), including isolates MN-2, Unk-1, Unk-2, Unk-4, Unk-5, Unk-6, Unk-7, Unk-8, and Unk-9, contained recombination junction sites at $\mathrm{HC} / \mathrm{Pro}-\mathrm{P} 3,6 \mathrm{~K} 2-\mathrm{NIa}$, and the $\mathrm{C}$ terminal region of $\mathrm{CP}$ gene (Tables 3 and 4). According to previous reports, isolates containing these three recombination sites have been categorized as being of European origin (22). The largest group, and perhaps the most prevalent, were field isolates that contained only one of the three known recombination junctions. A total of 158 field isolates were shown to produce the 641-bp product (Table 3), corresponding to the HC/Pro-P3 gene region junction site. Only one PVY ${ }^{\mathrm{N} / \mathrm{NTN}}$ field isolate (NE-11) did not contain any of the three known recombination junction sites, similar to the nonrecombinant control isolate Tu 660 (Table 4). Tu 660 was previously reported as not being a recombinant isolate and characterized as NA PVYNTN $(22)$.

A third RT-PCR assay, which detects segments of the P1 gene using forward primers S3, S5, and S6 along with the single reverse primer A, produced amplified PCR products of $745 \mathrm{bp}$ for Eu PVY ${ }^{\mathrm{N} / \mathrm{NTN}}, 554$ bp for NA PVY ${ }^{\mathrm{NTN}}$, and 443 bp for all $\mathrm{PVY}^{\mathrm{N} / \mathrm{NTN}}$, respectively (Fig. 3). Initially this assay was performed using only the two nonrecombinant $\mathrm{PVY}^{\mathrm{N} / \mathrm{NTN}}$ isolates, control isolate Tu 660 and the field isolate NE-11, to determine differences between these two isolates. Tu 660 produced two PCR products of $554 \mathrm{bp}$ for nonrecombinant NA PVY ${ }^{\mathrm{NTN}}$ and $443 \mathrm{bp}$ for all PVY ${ }^{\mathrm{N} / \mathrm{NTN}}$, as expected $(21,23)$. However, field isolate NE11 only produced a single product of $443 \mathrm{bp}$. In the absence of a full-length nucleotide sequence, results of the RT-PCR assays can only indicate that NE-11 most closely resembles the NA PVY ${ }^{\mathrm{NTN}}$ isolate, based on serology, bioassay, and the lack of recombination junction sites depicted in the recombinant point RT-PCR assay (Fig. 3; Table 4). The remaining PVY $\mathrm{PY}^{\mathrm{N} / \mathrm{NTN}}$ field isolates (183 total) were screened using the triplex RT-PCR but produced the 443-bp product along with a 745-bp product, indicating a relationship to Eu PVY $\mathrm{PY}^{\mathrm{N} / \mathrm{NTN}}$ (Table 3).

Biological characteristics of viral isolates on tobacco and potato. Of the $58 \mathrm{PVY}$ field isolates transmitted to tobacco, 11

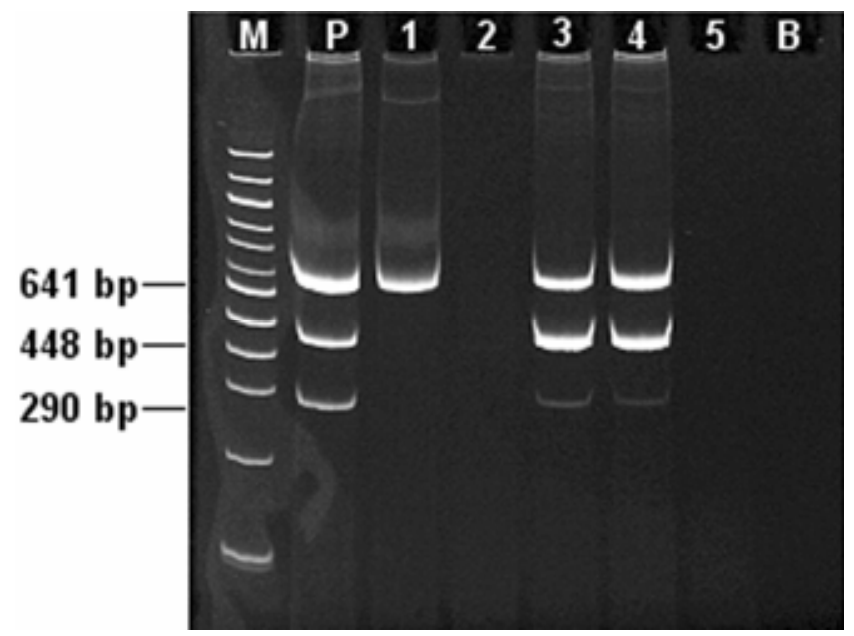

Fig. 2. Recombinant point reverse transcription-polymerase chain reaction detecting known recombination junction sites within the viral genome from representative Potato virus $Y$ (PVY) isolates using RNA isolated from tobacco plants. Lane M, 100-bp DNA ladder; lane P, positive control; lane 1, one recombination point indicative of $\mathrm{PVY}^{\mathrm{N}: \mathrm{O}}$ recombinant; lane 2, no recombination points indicative of $\mathrm{PVY}$; lanes 3 and 4, three recombination points (indicative of European PVY ${ }^{\mathrm{NTN}}$ ); lane 5, no recombination points indicative of North American PVYNTN; and lane B, negative control. 
isolates (including the control isolate $\mathrm{PVY}^{\mathrm{O}}$-139) produced a mild mosaic symptom that affected all new growth (Fig. 4A; Table 4). This phenotype is in agreement with serological and molecular data, identifying the 11 isolates as $\mathrm{PVY}^{\mathrm{O}}$. The remaining 47 field isolates induced varying degrees of leaf necrosis (Fig. 4B; Table 4), including veinal necrosis, severe stunting of the plant, and leaf death indicative of PVYN . These isolates had been categorized as belonging to the PVY ${ }^{\mathrm{N} / \mathrm{NTN}}$ group by the duplex RT-PCR, even though they had mixed reactions by ELISA and were found to contain varying numbers of recombination junction sites depicted in the recombinant point RT-PCR assay (Table 4).

Thirteen field isolates and one control isolate (Tu 660) transmitted from tobacco to potato produced PTNRD symptoms (Table 4). Ten of the PTNRD-inducing isolates produced typical external rings that were swollen and raised immediately after harvest but became sunken and necrotic after being stored at room temperature for 2 weeks (Fig. 5A and B). Of these 10 typical PTNRD-inducing isolates, eight (MN-2, Unk-1, Unk-2, Unk-4, Unk-5, Unk-6, Unk-8, and Unk-9) contained the three recombination junction sites detected by the multiplex RT-PCR assay. The remaining two isolates (NE-11 and control isolate Tu 660) did not possess any of the known recombination sites detected by the RTPCR assay (Table 4). The remaining four PTNRD-inducing isolates (MN-1, ND-25, OR-1, and NV-1) did not produce the typical external ring pattern, instead they produced a roughly circular, sunken necrotic lesion on the surface of the tuber (Fig. 5C), which was evident at the time of harvest. These four isolates contained only one of the known recombination junction sites and could be considered PVY ${ }^{\mathrm{N}: \mathrm{O}}$ recombinants because of their serological relationship to $\mathrm{PVY} \mathrm{Y}^{\mathrm{O}}$ and their ability to induce necrotic symptoms in tobacco but differ in that they are able to produce PTNRD symptoms (Table 4). The remaining 34 isolates inoculated to potato plants did not produce PTNRD symptoms and therefore most closely resemble the recombinant $\mathrm{PVY}^{\mathrm{N}: \mathrm{O}}$ isolates of PVY ${ }^{\mathrm{N}}$-Wilga, I-L56, and I-136 based on serology and biological data. Tuber necrosis was not observed on any tubers from uninoculated healthy control plants or from plants inoculated with the control isolate $\mathrm{PVY}^{\mathrm{O}}-139$.

\section{DISCUSSION}

PVY is a diverse virus species. Efforts to logically separate and classify PVY isolates into pathotypes or strains has proven to be challenging. With recent reports demonstrating the existence of various PVY pathotypes in North America based on both molecular and biological properties $(5,25,30)$, our efforts have been focused on determining the pathogenic nature of these isolates with respect to the induction of PTNRD. The goal of this research was to characterize and differentiate PVY field isolates obtained from various potato production regions in the United States. Further, we wanted to assess the PVY population to determine the frequency with which field isolates group into the current classification of PVY strains and to distinguish field isolates that are able to induce PTNRD. Results from our studies clearly demonstrate limitations of the current PVY classification system with respect to tuber necrosis.

We conclude that PVY field isolates found within the United States group into at least eight different PVY pathotypes: the previously defined categories of $\mathrm{PVY}^{\mathrm{O}}$, NA PVY ${ }^{\mathrm{NTN}}$, Eu PVY ${ }^{\mathrm{NTN}}$, and recombinant $\mathrm{PVY} \mathrm{Y}^{\mathrm{N}: \mathrm{O}}$ along with four categories that do not fit into the current PVY pathotype definitions. Leaf and tuber samples were collected from various potato production areas. Interestingly, we did not receive any samples that were infected with multiple PVY pathotypes nor did we collect any samples that were infected with $\mathrm{PVY}^{\mathrm{N}}$. In general, PVY isolates from each pathogroup were found dispersed throughout the midwestern and western United States and were not limited or localized to any one particular region. $\mathrm{PVY} \mathrm{Y}^{\mathrm{O}}$ isolates comprised only about $5 \%$ of the total isolates received. The $\mathrm{PVY} \mathrm{O}^{\mathrm{O}}$ isolates grouped into

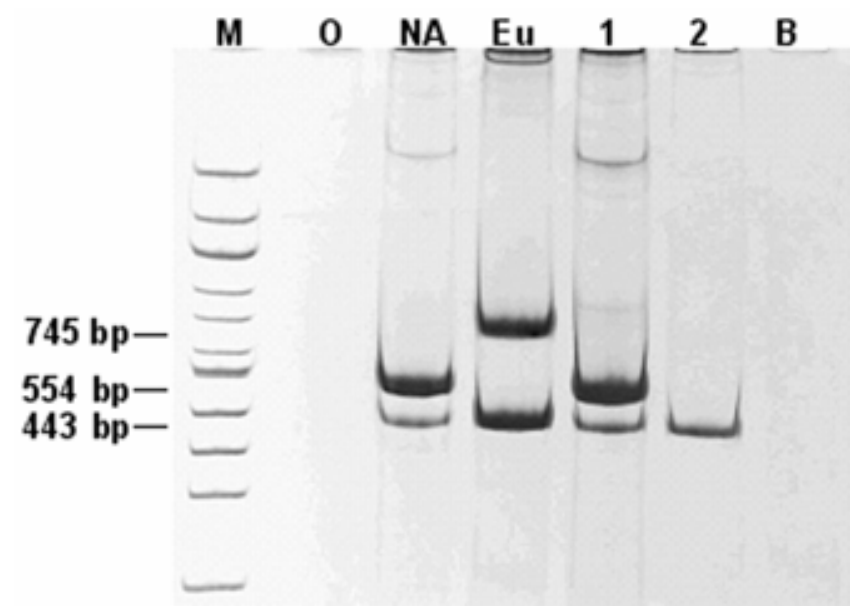

Fig. 3. Triplex reverse transcription-polymerase chain reaction detecting segments of the P1 gene using primers S3, S5, S6, and A to differentiate the two nonrecombinant isolates from representative Potato virus $Y$ (PVY) isolates using RNA extracted from tobacco plants. Lane M, 100-bp DNA ladder; lane $\mathrm{O}, \mathrm{PVY}^{\mathrm{O}}$ positive control; lane NA, North American PVY ${ }^{\mathrm{NTN}}$ positive control; lane Eu, European PVY ${ }^{\mathrm{N} / \mathrm{NTN}}$ positive control; lane 1, control isolate Tu 660; lane 2, field isolate NE-11; and lane B, negative control.

TABLE 4. Summary of complete biological, serological, and molecular characterization of 58 selected Potato virus $Y$ (PVY) field isolates

\begin{tabular}{|c|c|c|c|c|c|c|c|c|}
\hline Group & PVY strain & $\begin{array}{l}\text { Representative } \\
\text { isolate }\end{array}$ & $\begin{array}{l}\text { Total no. of } \\
\text { isolates }^{\mathrm{a}}\end{array}$ & $\begin{array}{c}\text { Antigen } \\
\text { specificity }\end{array}$ & $\begin{array}{l}\text { P1 gene } \\
\text { products }^{\mathrm{c}}\end{array}$ & $\begin{array}{l}\text { Recombination } \\
\text { points }^{\mathrm{d}}\end{array}$ & $\begin{array}{c}\text { Tobacco } \\
\text { symptoms }\end{array}$ & $\begin{array}{c}\text { Tuber } \\
\text { symptoms }\end{array}$ \\
\hline I & $\mathrm{PVY}^{\mathrm{O}}$ & $P V Y^{0}-139^{g}$ & 11 & $4 \mathrm{C} 3+\mathrm{MAB} 2$ & $281 \mathrm{bp}$ & 0 & M & None \\
\hline II & Eu PVY ${ }^{\mathrm{NTN}}$ & $\mathrm{MN}-2$ & 3 & $4 \mathrm{C} 3+1 \mathrm{~F} 5$ & $443,745 \mathrm{bp}$ & 3 & $\mathrm{LN}$ & Typical \\
\hline $\mathrm{IV}^{\mathrm{h}}$ & & Unk-7 & 1 & $4 \mathrm{C} 3+\mathrm{MAB} 2+1 \mathrm{~F} 5$ & $443,745 \mathrm{bp}$ & 3 & $\mathrm{LN}$ & None \\
\hline $\mathrm{V}$ & NA PVY ${ }^{N T N}$ & Tu $660^{\mathrm{g}}$ & 1 & $4 \mathrm{C} 3+1 \mathrm{~F} 5$ & $443,554 \mathrm{bp}$ & 0 & $\mathrm{LN}$ & Typical \\
\hline $\mathrm{VI}^{\mathrm{h}}$ & & NE-11 & 1 & $4 \mathrm{C} 3+1 \mathrm{~F} 5$ & $443 \mathrm{bp}$ & 0 & $\mathrm{LN}$ & Typical \\
\hline $\mathrm{VII}^{\mathrm{h}}$ & & OR-1 & 4 & $4 \mathrm{C} 3+\mathrm{MAB} 2$ & $443,745 \mathrm{bp}$ & 1 & $\mathrm{LN}$ & Atypical \\
\hline
\end{tabular}

${ }^{a}$ Represents number out of 60 isolates characterized, 58 field and 2 control isolates.

${ }^{b}$ Produced a positive absorbance value using specified monoclonal antibodies: 4C3 for all PVY, MAB2 for PVY ${ }^{\mathrm{O}+\mathrm{C}}$, and $1 \mathrm{~F} 5$ for PVYN

${ }^{\mathrm{c}}$ Possible P1 gene RT-PCR amplified products: $281 \mathrm{bp}=\mathrm{PVY}^{\mathrm{O}}, 443 \mathrm{bp}=$ all PVYN/NTN, $554 \mathrm{bp}=$ North American $(\mathrm{NA}) \mathrm{PVY}$ NTN, and $745 \mathrm{bp}=$ European $($ Eu) PVYNTN.

${ }^{\mathrm{d}}$ Recombination points: $0=$ no known recombination junctions sites, $1=$ recombination junction at HC/Pro-P3 region $(641 \mathrm{bp}), 3=$ recombination junctions at HC/Pro-P3 (641 bp), 6K2-NIa (441 bp), and C-terminal region of coat protein (290 bp).

e Tobacco foliar symptoms: $\mathrm{M}=$ mosaic, $\mathrm{LN}=$ leaf necrosis.

${ }^{\mathrm{f}}$ Tuber symptoms: typical $=$ external ring pattern, atypical $=$ roughly circular, sunken necrotic lesion, and none $=$ no symptoms produced.

g Control isolates $\mathrm{PVY}^{\mathrm{O}}-139\left(\mathrm{PVY}^{\mathrm{O}}\right)$ and Tu $660\left(\mathrm{NA} \mathrm{PVY}^{\mathrm{NTN}}\right)$.

${ }^{\text {h }}$ Category does not fit previously defined PVY strain grouping. 
the typical classification scheme by ELISA using monoclonal antibodies 4C3 and MAB2, inducing only mosaic symptoms on cv. Samsun tobacco and producing the 281-bp RT-PCR product of the $\mathrm{P} 1$ gene. All of these results are indicative of $\mathrm{PVY}$ $(15,21)$.

Formerly, all PTNRD-inducing isolates were combined under a single category known simply as PVY ${ }^{\mathrm{NTN}}$, independent of geographic origin or genomic structure. The prerequisites for classification of PVYNTN were to be serologically related to $\mathrm{PVY}^{\mathrm{N}}$ and to induce PTNRD symptoms in potatoes. Recently, a combination of RT-PCR assays utilizing sequences within the $5^{\prime}$-untranslated region, $\mathrm{P} 1$ gene, and known recombination junction sites of the PVY genome has led to the separation of isolates recovered from Europe from those isolated in North America $(21,22)$. Our re-
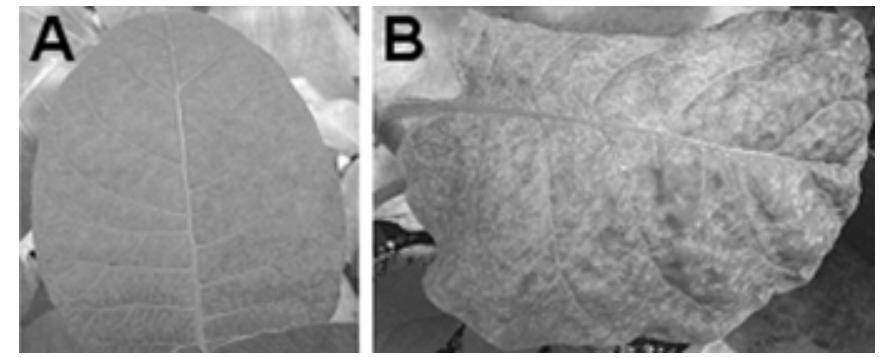

Fig. 4. Foliar symptoms on cv. Samsun tobacco leaves: A, mosaic symptoms typical of $\mathrm{PVY} \mathrm{Y}^{\mathrm{O}}$ (Potato virus $Y$ ) isolates and $\mathbf{B}$, veinal and leaf necrosis indicative of $\mathrm{PVY} \mathrm{Y}^{\mathrm{N} / \mathrm{NTN}}$ isolates. search corroborates previous reports of isolates categorized as NA PVY ${ }^{\text {NTN }}$ possessing a nonrecombinant genome based on RT-PCR as opposed to the recombinant Eu PVY ${ }^{\text {NTN }}$ group (22). Both of these groups are serologically related to $\mathrm{PVY}^{\mathrm{N}}$, have been shown to induce veinal necrosis in cv. Samsun tobacco, and produce the typical necrotic ring pattern on the surface of tubers. The single nonrecombinant NA PVY ${ }^{\mathrm{NTN}}$ isolate found comprised less than $1 \%$ of the PVY population studied. This was surprising given the recent attention this pathotype has received in literature. Of particular importance to us was the detection of several isolates grouped under the classic definition of Eu PVYN/NTN, all of which contain a segment of the P1 gene that produces a 745-bp fragment by RT-PCR. To our knowledge, this is the first detailed report of Eu PVY ${ }^{\text {N/NTN }}$ in North America (25). The 745-bp fragment, indicative of a Eu PVY ${ }^{\mathrm{N} / \mathrm{NTN}}$, also was found in the PVY ${ }^{\mathrm{N}: \mathrm{O}}$ recombinant isolates, the most common pathotype found within our population of field isolates.

Recent reports have indicated the possible detection of recombinant $\mathrm{PVY}^{\mathrm{N}: \mathrm{O}}$ isolates obtained from tubers grown in northwestern United States $(5,25)$. These PVY ${ }^{\mathrm{N}: \mathrm{O}}$ recombinant isolates were reported as being similar to the PVY ${ }^{\mathrm{N}}$-Wilga strain found in Europe (3), as well as isolates PVY ${ }^{\mathrm{N}}$-I-L56 and I-136 obtained from Canada $(17,19)$, in that they are serologically related to $\mathrm{PVY}^{\mathrm{O}}$ and contain a recombinant genomic structure. However, none of these isolates have been reported to induce PTNRD. The $\mathrm{PVY}^{\mathrm{N}: \mathrm{O}}$ recombinant isolates found in Europe appear to have a high multiplication and spread rate $(4,32)$ and may constitute $90 \%$ of the total PVYN population in Europe $(4,11)$. A majority of our field isolates that were fully characterized by serological, molecu-
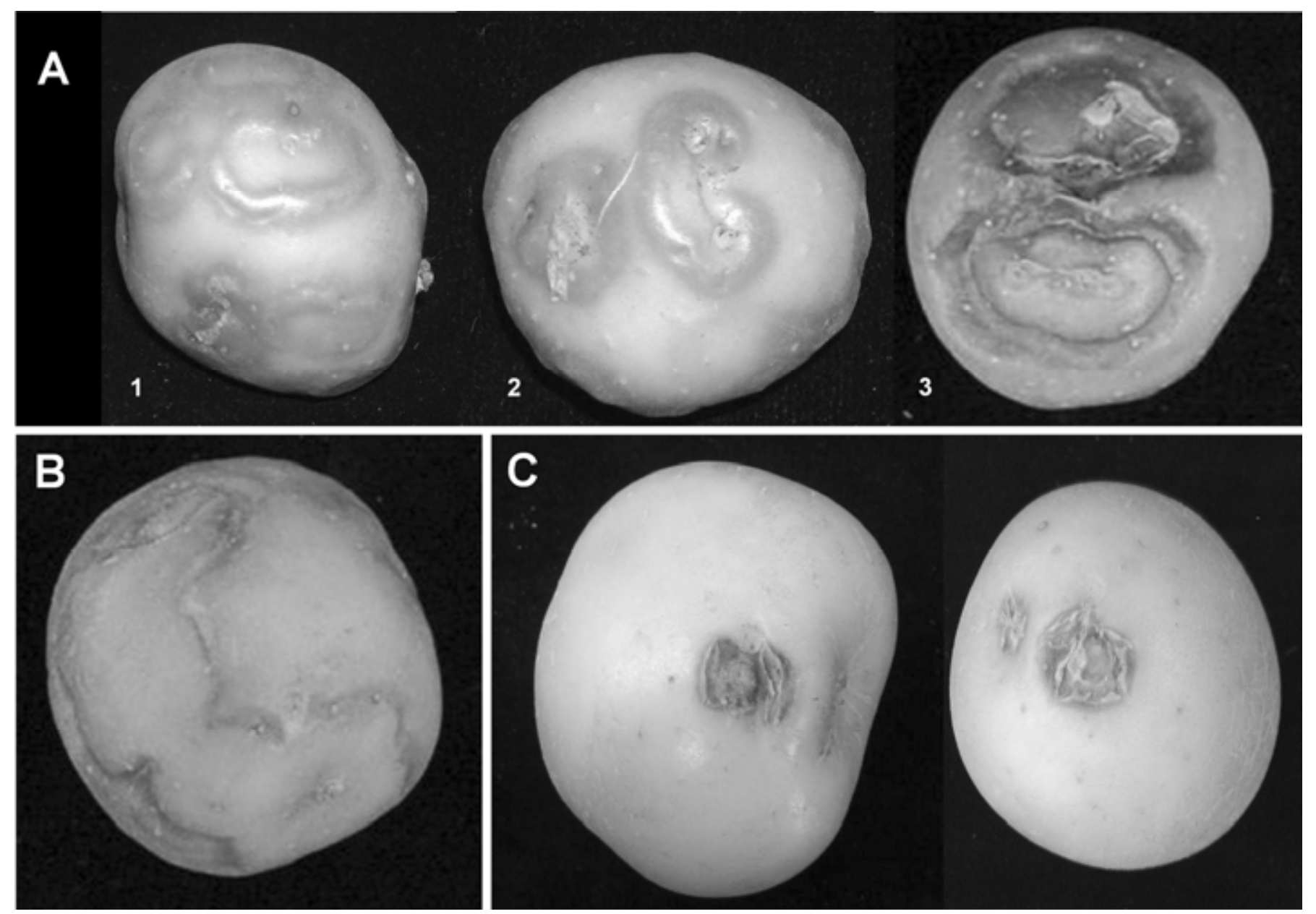

Fig. 5. Tuber symptoms on potato cv. Yukon Gold, harvested 70 days after inoculation. A, Typical European PVYNTN (Potato virus $Y$ ) tuber symptoms at time of harvest (potatoes 1 and 2) versus storage after 2 weeks (potato 3); B, typical North American PVY ${ }^{\mathrm{NTN}}$ tuber symptoms; and $\mathbf{C}$, atypical PVY ${ }^{\mathrm{N}: \mathrm{O}}$ recombinant tuber symptoms. 
lar, and biological assays were classified as recombinant $\mathrm{PVY} \mathrm{Y}^{\mathrm{N}: \mathrm{O}}$. Our findings agree with those reported in Europe and in North America (30), in that PVY ${ }^{\mathrm{N}: \mathrm{O}}$ pathotypes appear to predominate. These isolates all react to the $\mathrm{PVY}^{\mathrm{O}}$ coat protein antibody and cause veinal necrosis in tobacco indicator plants. However, several of the $\mathrm{PVY}^{\mathrm{N}: \mathrm{O}}$ recombinant isolates that we detected did not fit within the previously published definition of $\mathrm{PVY}^{\mathrm{N}: \mathrm{O}}$ because they clearly induce PTNRD in the highly susceptible potato cv. Yukon Gold. This is the first report of recombinant PVY ${ }^{\mathrm{N}: \mathrm{O}}$ isolates that are capable of inducing tuber necrosis in potato.

The PTNRD symptoms produced by the PVY ${ }^{\mathrm{N}: \mathrm{O}}$ recombinants were atypical compared with lesions found on the same cultivar infected with either the Eu PVY ${ }^{\mathrm{NTN}}$ or the NA PVY ${ }^{\mathrm{NTN}}$ isolates. Instead, the PVY ${ }^{\mathrm{N}: \mathrm{O}}$ recombinants produced a single, roughly circular necrotic lesion on the surface of the tuber as opposed to the typical external sunken ring pattern displayed by PVY ${ }^{\mathrm{NTN}}$ isolates. These atypical lesions are very subtle compared with the well-defined PTNRD symptoms of PVYNTN and could easily be mistaken for another potato disease, such as Fusarium dry rot, if based solely upon visual inspection (24).

Recombinant $\mathrm{PVY}^{\mathrm{N}: \mathrm{O}}$ field isolates also were found within the same potato production regions as field isolates that did not produce PTNRD symptoms using our assays. Because of this biological characteristic, these field isolates more closely resemble the PVY ${ }^{\mathrm{N}}$-Wilga and isolates I-L56 and I-136 $(3,17,19)$. These isolates (including PVY ${ }^{\mathrm{N}}$-Wilga, I-L56, and I-136), along with the PTNRD-producing PVY ${ }^{\mathrm{N}: \mathrm{O}}$ recombinants, are all identical based on current serological and biological testing procedures. It would be advantageous to analyze the genomic structure of these two groups of isolates at the nucleotide level to determine the portion, or portions, of the genome responsible for tuber necrosis. Because such great diversity is found just within the United States alone, it will be very difficult to categorize and detect all PVY ${ }^{\text {NTN }}$ isolates, independent of their geographical region and genomic structure. In the absence of a single diagnostic tool that is capable of unambiguously differentiating all isolates of PVY, it is likely that isolates of PVY ${ }^{\mathrm{N}: \mathrm{O}}$ and $\mathrm{PVY} \mathrm{NTN}^{\mathrm{NTN}}$ will continue to increase in occurrence throughout North America. Thus, PVY management in North America should emphasize reduction of PVY inoculum irrespective of the pathotype involved.

\section{ACKNOWLEDGMENTS}

We thank the USDA-ARS for financial support (grant 59-0790-3-066); N. Podugu, G. Secor, and V. Rivera-Varas for laboratory technical assistance; and D. Peterson, D. Nilles, and D. Serfling for greenhouse assistance.

\section{LITERATURE CITED}

1. Beczner, L., Horváth, H., Romhányi, I., and Förster, H. 1984. Studies on the etiology of tuber necrotic ringspot disease in potato. Potato Res. 27:339-352.

2. Boonham, N., Walsh, K., Preston, S., North, J., Smith, P., and Barker, I. 2002. The detection of tuber necrotic isolates of Potato virus $Y$, and the accurate discrimination of $\mathrm{PVY}^{\mathrm{O}}, \mathrm{PVY}^{\mathrm{N}}$, and $\mathrm{PVY}^{\mathrm{C}}$ strains using RTPCR. J. Virol. Methods 102:103-112.

3. Chrzanowska, M. 1991. New isolates of the necrotic strain of Potato virus $Y\left(\mathrm{PVY}^{\mathrm{N}}\right)$ found recently in Poland. Potato Res. 34:179-182.

4. Chrzanowska, M. 2001. Importance of different strains of PVY in potato production and breeding program in Poland. Pages 12-14 in: Proc. 11th Eur. Assoc. Potato Res. Virol. Sec., Potato Research Institute, Havlíčkův Brod, Czech Republic.

5. Crosslin, J. M., Hamm, P. B., Eastwell, K. C., Thornton, R. E., Brown, C. R., Corsini, D., Shiel, P. J., and Berger, P. H. 2002. First report of the necrotic strain of Potato virus $Y\left(\mathrm{PVY}^{\mathrm{N}}\right)$ on potatoes in the northwestern United States. Plant Dis. 86:1177.

6. Domier, L. L., Shaw, J. G., and Rhoads, R. E. 1987. Potyviral proteins share amino acid sequence homology with picorna-, como-, and caulimoviral proteins. Virology 158:20-27.

7. Draper, M. D., Pasche, J. S., and Gudmestad, N. C. 2002. Factors influencing PVY development and disease expression in three potato cultivars. Am. J. Potato Res. 79:155-165.

8. Glais, L., Tribodet, M., and Kerlan, C. 2002. Genomic variability in Potato potyvirus $Y$ (PVY): Evidence that $\mathrm{PVY}^{\mathrm{N}} \mathrm{W}$ and $\mathrm{PVY} \mathrm{YTN}^{\mathrm{NTN}}$ variants are single to multiple recombinants between $\mathrm{PVY}^{\mathrm{O}}$ and $\mathrm{PVY}^{\mathrm{N}}$ isolates. Arch. Virol. 147:363-378.

9. Hane, D. C., and Hamm, P. B. 1999. Effects of seedborne Potato virus $Y$ infection in two potato cultivars expressing mild disease symptoms. Plant Dis. 83:43-45.

10. Jones, R. A. C. 1990. Strain group specific and virus specific hypersensitive reactions to infection with potyviruses in potato cultivars. Ann. Appl. Biol. 117:93-105.

11. Kaczmarek, U., and Mosakowska, E. 2001. Interaction between strains of the Potato virus $Y\left(\mathrm{PVY}^{\mathrm{O}}, \mathrm{PVY}^{\mathrm{N}}\right.$-type Wilga, PVY $\left.{ }^{\mathrm{NTN}}\right)$ and the potato plants of two cultivars. Pages 18-20 in: Proc. 11th Eur. Assoc. Potato Res. Virol. Sec. Potato Research Institute, Havlíčkův Brod, Czech Republic.

12. Kerlan, C., Tribodet, M., Glais, L., and Guillet, M. 1999. Variability of Potato virus $Y$ in potato crops in France. J. Phytopathol. 147:643-651.

13. Le Romancer, M., Kerlan, C., and Nedellec, M. 1994. Biological characterization of various geographical isolates of Potato virus $Y$ inducing superficial necrosis on potato tubers. Plant Pathol. 43:138-144.

14. Marie-Jeanne Tordo, V., Chachulska, A. M., Fakhfakh, H., Le Romancer, M., Robaglia, C., and Astier-Manifacier, S. 1995. Sequence polymorphism in the 5'NTR and in the P1 coding region of Potato virus $Y$ genomic RNA. J. Gen. Virol. 76:939-949.

15. McDonald, J. G., and Kristjansson, G. T. 1993. Properties of strains of Potato virus $Y^{\mathrm{N}}$ in North America. Plant Dis. 77:87-89.

16. McDonald, J. G., and Singh, R. P. 1993. Assessment of North American isolates of $\mathrm{PVY}^{\mathrm{N}}$ for strains that induce tuber ring necrosis disease. Am. Potato J. 70:827.

17. McDonald, J. G., and Singh, R. P. 1996. Host range, symptomology, and serology of isolates of Potato virus $Y$ (PVY) that share properties with both the PVY ${ }^{\mathrm{N}}$ and $\mathrm{PVY} \mathrm{O}^{\mathrm{O}}$ strain groups. Am. Potato J. 73:309-315.

18. McDonald, J. G., and Singh, R. P. 1996. Response of potato cultivars to North American isolates of PVYNTN. Am. Potato J. 73:317-323.

19. McDonald, J. G., Wong, E., Henning, D., and Tao, T. 1997. Coat protein and $5^{\prime}$ nontranslated region of a variant of Potato virus Y. Can. J. Plant Pathol. 19:138-144.

20. Nie, X., and Singh, R. P. 2002. Probable geographical grouping of PVYN and PVYNTN based on sequence variation in P1 and $5^{\prime}$-UTR of PVY genome and methods for differentiating North American PVYNTN. J. Virol. Methods 103:145-156.

21. Nie, X., and Singh, R. P. 2002. A new approach for the simultaneous differentiation of biological and geographical strains of Potato virus $Y$ by uniplex and multiplex RT-PCR. J. Virol. Methods 104:40-54.

22. Nie, X., and Singh, R. P. 2003. Specific differentiation of recombinant PVY ${ }^{\mathrm{N}: \mathrm{O}}$ and PVY ${ }^{\mathrm{NTN}}$ isolates by multiplex RT-PCR. J. Virol. Methods 113:69-77.

23. Nie, X., and Singh, R. P. 2003. Evolution of North American PVYNTN strain Tu 660 from local $\mathrm{PVY}^{\mathrm{N}}$ by mutation rather than recombination. Virus Genes 26:39-47.

24. Ohshima, K., Sako, K., Hiraishi, C., Nakagawa, A., Matsuo, K., Ogawa, T., Shikata, E., and Sako, N. 2000. Potato tuber necrotic ringspot disease occurring in Japan: Its association with Potato virus $Y$ necrotic strain. Plant Dis. 84:1109-1115.

25. Shiel, P. J., Kopp, H. T., and Berger, P. H. 2003. Biological and molecular characterization of Potato virus $Y$ from potato. (Abstr.) Phytopathology 93(suppl.):S78.

26. Singh, M., and Singh, R. P. 1994. A fast-reacting bioassay for the tobacco veinal necrosis strain of Potato virus $Y\left(\mathrm{PVY}^{\mathrm{N}}\right)$. Plant Dis. 78:775-778.

27. Singh, M., and Singh, R. P. 1996. Nucleotide sequence and genome organization of a Canadian isolate of the common strain of Potato virus $Y$ $\left(\mathrm{PVY}^{\mathrm{O}}\right)$. Can. J. Plant Pathol. 18:209-224.

28. Singh, R. P. 1992. Incidence of the tobacco veinal necrotic strain of Potato virus $Y\left(\mathrm{PVY}^{\mathrm{N}}\right)$ in Canada in 1990 and 1991 and scientific basis for eradication of the disease. Can. Plant Dis. Surv. 72:113-119.

29. Singh, R. P., and Boucher, A. 1992. Comparison of tobacco cultivars for the detection of $\mathrm{PVY}^{\mathrm{N}}$ from mixed infection of PVX and $\mathrm{PVY}^{\mathrm{O}}$. Am. Potato J. 69:607.

30. Singh, R. P., McLaren, D. L., Nie, X., and Singh, M. 2003. Possible escape of a recombinant isolate of Potato virus $Y$ by serological indexing and methods of its detection. Plant Dis. 87:679-685.

31. Smith, K. M. 1931. Composite nature of certain potato viruses of the mosaic group. Nature 127:702.

32. Turska, E., and Daczmarek, U. 2001. Occurrence of the Potato virus $Y$ strains (PVY) during long-term multiplication of some potato cultivars in Poland. Pages 21-24 in: Proc. 11th Eur. Assoc. Potato Res. Virol. Sec. Potato Research Institute, Havlíčkův Brod, Czech Republic.

33. Van den Heuvel, J. F. J. M., Van der Vlugt, R. A. A., Verbeek, M., De 
Haan, P. T., and Huttinga, H. 1994. Characteristics of a resistancebreaking isolate of Potato virus $Y$ causing potato tuber necrotic ringspot disease. Eur. J. Plant Pathol. 100:347-356.

34. Weidemann, H. L., and Maiss, E. 1996. Detection of the potato tuber necrotic ringspot strain of Potato virus $Y$ (PVY $\left.{ }^{\mathrm{NTN}}\right)$ by reverse transcription and immunocapture polymerase chain reaction. J. Plant Dis. Prot. $103: 337-345$.
35. Weidemann, H. L., Rüffert, C., and Maiss, E. 1995. Identification of the tuber necrotic ringspot strain of Potato virus $Y$ (PVY ${ }^{\mathrm{NTN}}$ ). (Abstr.) Pages 105-109 in: Proc. 9th Eur. Assoc. Potato Res. Virol. Sec. Potato Research Institute, Havlíčkův Brod, Czech Republic.

36. Weilguny, H., and Singh, R. P. 1998. Separation of Slovenian isolates of PVYNTN from the North American isolates of PVY ${ }^{\mathrm{N}}$ by a 3-primer PCR. J. Virol. Methods 71:57-68. 